\title{
Raising Healthy Children: Health Risks of Obesity ${ }^{1}$
}

\author{
Stephanie Meyer, Karla Shelnutt, and Gail Kauwell ${ }^{2}$
}

Although babies need fat for warmth and normal growth, as children develop, too much fat can be unhealthy. Childhood obesity may result in health problems early in life and into adulthood. This publication will help you understand the health risks of obesity and ways to help your child maintain a healthy weight.

\section{What Is Obesity?}

Obesity is too much body fat and is most often determined by measuring Body Mass Index (BMI), which is based on height and weight (American Obesity Association, 2002). The number of children who are obese has tripled over the past 40 years (CDC, 2011c). In 2011, the Centers for Disease Control and Prevention (CDC) reported that 17\% of U.S. children and adolescents (2-19 years) were obese (U.S. Department of Health and Human Services, 2012). Children who are African-American, Mexican-American, or American-Indian have a higher risk of obesity than non-Hispanic white children (U.S. Department of Health and Human Services, 2012; Jackson, 1993).

\section{What Causes Obesity?}

Although genetic factors can cause obesity, childhood obesity is mostly a result of children eating more and moving less (CDC, 2011c). This means that children may spend more time in front of a television or computer screen with less time spent outside being active (CDC, 2012).

Also, children watching television or on the computer are exposed to ads promoting foods high in fat and sugar and low in important nutrients (Dietz, Bandini, Morelli, Peers, \& Ching, 1994).

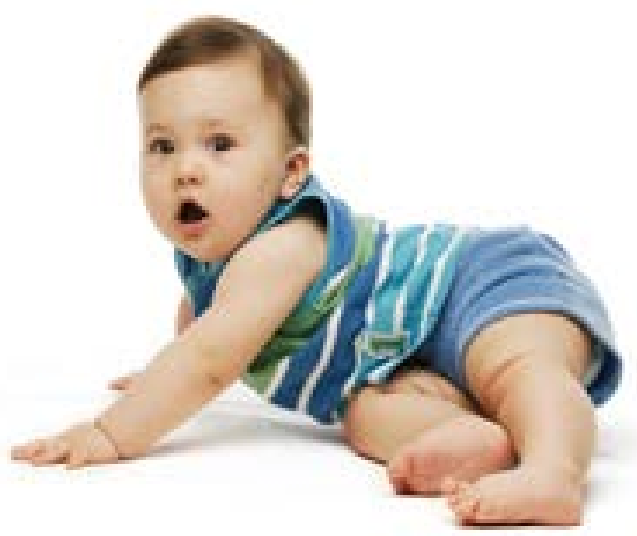

Figure 1. Babies need fat for normal growth, but as they develop into children too much fat can be unhealthy.

Credits: iStockphoto

These media messages are not the only way that children's food choices are influenced. Access to unhealthy foods is a major factor of obesity. At some schools, foods high in fat and sugar and drinks with added sugar may be offered through vending or food retailers. Many states have eliminated soda from school vending machines, but other drinks with added sugars, such as sports and fruit drinks, may still be available (CDC, 2011a).

At home, parents determine the food available to children and are the most influential factor in a child's development

1. This document is FCS80023, one of a series of the Department of Family, Youth, and Community Sciences, Florida Cooperative Extension Service, Institute of Food and Agricultural Sciences, University of Florida. First published April 2013. Please visit the EDIS website at http://edis.ifas.ufl.edu.

2. Stephanie Meyer, dietetic intern, Master of Science-Dietetic Internship Program, Food Science and Human Nutrition Department; Karla P. Shelnutt, PhD, RD, assistant professor, Department of Family, Youth and Community Sciences; and Gail P.A. Kauwell, PhD, RD, professor, Food Science and Human Nutrition Department; Florida Cooperative Extension Service, Institute of Food and Agricultural Sciences, University of Florida, Gainesville, FL 32611. 
of food preferences and activity (Rozin, 1990; Fogelholm, Nuutinen, Pasanen, Myohanen, \& Saatela, 1999). The amount of fat in a child's diet is influenced by the mother's diet; if the mother's diet is high in fat, it may lead to the development of obesity in children (Nguyen, Larson, Johnston, \& Goran, 1996). Similarly, parent inactivity can be related to child inactivity (Fogelholm et al., 1999).

\section{What Are the Health Risks of Childhood Obesity?}

Childhood obesity has profound effects on a child's physical and mental health. Overweight children have an increased risk of developing diseases most commonly found in adults (Garn et al., 1975).

\section{Type 2 Diabetes}

Type 2 diabetes is a disease in which the body does not make enough insulin or the body's cells do not respond to it. Insulin helps your body use the food you eat for energy (American Diabetes Association, 2012). Without enough insulin, too much sugar ends up in the blood, making a child feel tired or sick. Obesity increases the risk for developing type 2 diabetes because too much fat in the body makes it hard for the cells to use insulin. Although this disease used to be rare in children, the prevalence is increasing, especially among African-American and Hispanic/Latino children (U.S. Department of Health and Human Services, 2012; CDC, 2011b). Based on CDC reports, an estimated one in three toddlers born in 2000 will develop diabetes in their lifetime (Anderson \& Whittaker, 2009).

\section{Heart Disease}

Obese children are at an increased risk for developing risk factors associated with heart disease, such as high blood pressure and high cholesterol, compared to children who maintain a healthy weight (Morrison, Barton, Biro, Daniels, \& Sprecher, 1999). This increased risk occurs during childhood and may extend into adulthood (CDC, 2013).

\section{Sleep Apnea}

With the increase in childhood obesity, more children are suffering from sleep apnea (Arens \& Muzumdar, 2010). It is a condition that causes breathing to become difficult or stop during sleep. The condition may be life threatening, cause disruptive sleep (American Thoracic Society Workshop, 1999), and negatively affect children's school performance and ability to focus (Gozal, 1998).

\section{Social Isolation and Bullying}

Other children may see an obese child as an undesirable friend, causing the child to experience social isolation (Richardson, Hastorf, Goodman, \& Dornbusch, 1961). This can negatively affect the obese child's well-being and emotional development (Strauss \& Pollack, 2003). These children may feel unworthy or ignored, which can lead to depression (Sjoberg, Nilsson, \& Leppert, 2005). Furthermore, an obese child is more likely to be a victim of bullying behavior or to be a bully toward other children (Janssen, Craig, Boyce, \& Pickett, 2004). The psychological effects linked with childhood obesity may even persist into adulthood.

\section{How Do I Know If My Child Is Obese?}

If you are concerned about your child's weight, talk to your child's pediatrician. She will calculate your child's BMI and use a BMI-for-age growth chart to determine if your child's weight is within a healthy range. For more detailed information on how to use and interpret BMI charts refer to the EDIS publication FY1193/FCS8923 Raising Healthy Children: BMI Charts (http://edis.ifas.ufl.edu/fy1193). Table 1 lists the BMI categories and their matching percentile range.

Table 1. BMI-for-age weight status categories and corresponding percentile ranges.

\begin{tabular}{|l|l|}
\hline $\begin{array}{l}\text { Weight Status } \\
\text { Category }\end{array}$ & Percentile Range \\
\hline Underweight & Less than the 5th percentile \\
\hline Healthy Weight & $\begin{array}{l}\text { 5th percentile to less than the 85th } \\
\text { percentile }\end{array}$ \\
\hline Overweight & $\begin{array}{l}\text { 85th percentile to less than the 95th } \\
\text { percentile }\end{array}$ \\
\hline Obese & $\begin{array}{l}\text { Equal to or greater than the 95th } \\
\text { percentile }\end{array}$ \\
\hline Source: CDC, 2011a. & \\
\hline
\end{tabular}

\section{What Can I Do To Prevent My Child from Becoming Obese?}

You can do many things to help your child maintain a healthy weight. Preventing your child from gaining too much weight is much easier than having to treat your child for obesity. Maintaining a healthy weight means ensuring that your child is eating enough calories to support normal growth and activity. Your whole family can even benefit from the steps you take to prevent your child from becoming obese. Engage your family using the following simple and fun tips for a healthy lifestyle! 
- Promote healthy eating habits: Provide your child with vegetables, fruits, and whole grains. Choose low-fat or non-fat dairy products, and replace fatty meats with lean meats, poultry, fish, and lentils.

- Serve reasonably sized portions: This will ensure your child is not eating too much food.

- Encourage your family to drink more water and less sweetened beverages: Beverages with added sugar provide extra calories with few other nutrients.

- Find and use healthy recipes: Make sure to involve your children in the cooking process!

- Replace foods high in sugar and saturated fats: Find healthy alternative options such as fruits or vegetables.

- Get regular physical activity: Take a brisk walk after dinner, play a game of soccer or tag on a Saturday afternoon, or do family fitness classes in the evening. Children often copy their parents, so the best way to get your kids moving is to move yourself!

- Spend less time in front of a screen: Reduce the time your children spend watching TV, playing video games, or surfing the web to no more than two hours a day. If your child is two or younger, it is recommended to avoid all screen time. Use the time your children are not in front of the screen to be active.

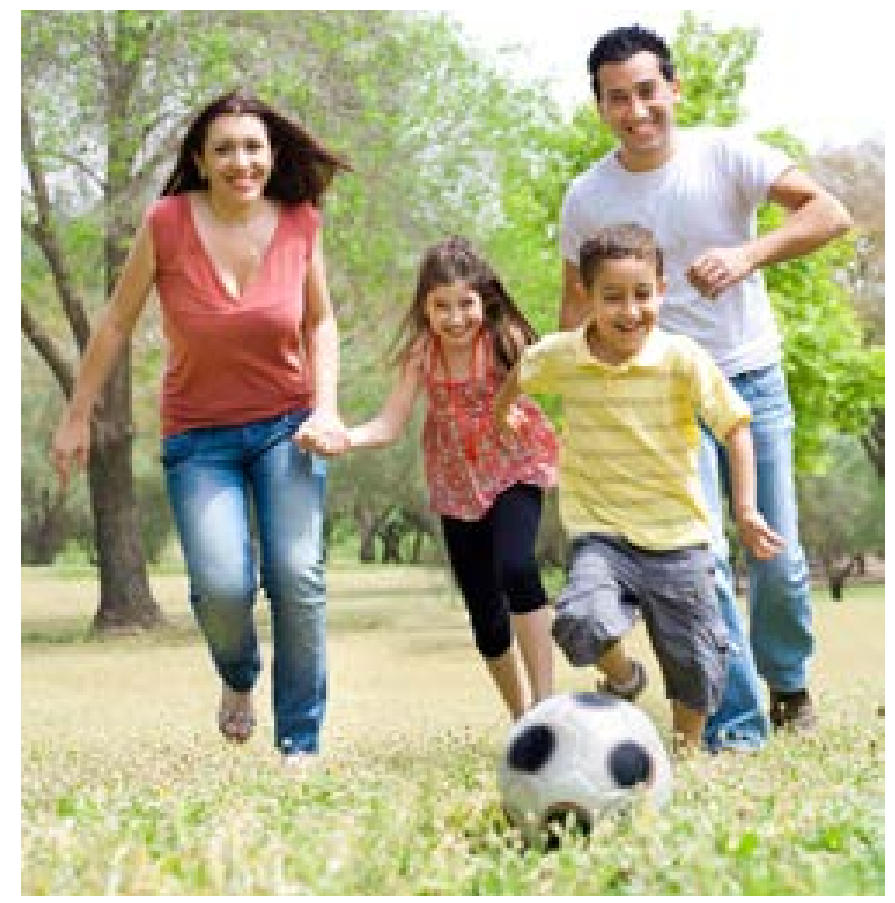

Figure 2. A good way to prevent obesity in your children is to make sure they get regular physical activity. Children are more likely to participate in exercise if parents participate as well.

Credits: iStockphoto

\section{What Can I Do If My Child Is Obese?}

If your child is obese or overweight, talk to your pediatrician about treatment. Treating obesity may prevent severe obesity-related diseases in adulthood (Golan, Weizman, Apter, \& Fainaru, 1998). By following the ideas in this publication to prevent obesity, you may be able to prevent further weight gain. A registered dietitian (RD) can also help you to ensure that your child is receiving the nutrients needed for growth while preventing further weight gain.

The goal for overweight and obese children is to slow the rate of weight gain while allowing for normal growth and development (CDC, 2011a). Children and adolescents should not be placed on a weight loss program without consulting a health care provider.

\section{Summary}

Obesity is a condition of having too much body fat, and it has many associated health risks. Obesity rates in children are rising because of increased food intake and decreased activity. To prevent childhood obesity, follow the tips in this guide such as getting active with your children and encouraging healthy eating. If you think your child may be overweight or obese, make an appointment with your pediatrician to learn how to slow the rate of weight gain while allowing for normal growth and development.

\section{Recommended Resources}

To learn more about childhood obesity and other nutrition topics, contact the Family and Consumer Sciences (FCS) agent at your county Extension office (see http://solutionsforyourlife.ufl.edu/map/ to find your local office). A registered dietitian (RD) also can provide you with reliable information on nutrition.

Also, you can find reliable information on the following websites:

USDA's MyPlate (http://www.choosemyplate.gov): This website provides resources and tips for healthy eating and physical activity. It also has activities for children about healthy food choices. This website is also available in Spanish at http://www.choosemyplate.gov/en-espanol.html.

Let's Move (http://www.letsmove.gov): This website is part of First Lady Michelle Obama's campaign to get America moving to raise a healthier generation. On this site you will find resources for healthy eating and tips on involving the whole family in physical activities. 


\section{References}

American Diabetes Association. (2012). Diabetes

basics: Type 2. Retrieved from http://www.diabetes.org/ diabetes-basics/type-2/

American Obesity Association. (2010). What is obesity? Retrieved from http://www.obesity.org/resources-for/whatis-obesity.htm

American Thoracic Society Workshop. (1999). Cardiorespiratory sleep studies in children: Establishment of normative data and polysomnographic predictors of morbidity. Am J Respir Crit Care Med 160(4):1381-1387.

Anderson, S.E., \& Whittaker R.C. (2009). Prevalence of obesity among US preschool children in different racial or ethnic groups. Arch Pediatr Adolesc Med.163(4):344-348.

Arens, H., \& Muzumdar, H. (2010). Childhood obesity and obstructive sleep apnea syndrome. J Appl Physiol. 108(2):436-444.

Centers for Disease Control and Prevention (CDC). (2013). Adolescents and school health: Childhood obesity facts. Retrieved from http://www.cdc.gov/healthyyouth/obesity/ facts.htm

CDC. (2011a). Healthy weight: It's not a diet, it's a lifestyle! Retrieved from http://www.cdc.gov/healthyweight/ children/\#

CDC. (2012). A growing problem. Retrieved from http:// www.cdc.gov/obesity/childhood/problem.html

CDC. (2011b). National diabetes fact sheet: National estimates and general information on diabetes and prediabetes in the United States, 2011. Atlanta, GA: U.S. Department of Health and Human Services, Centers for Disease Control and Prevention. Retrieved from http://www.cdc.gov/ diabetes/pubs/pdf/ndfs_2011.pdf

CDC. (2011c). Overweight and obesity: U.S. obesity trends. Retrieved from http://www.cdc.gov/obesity/data/trends. html.

Dietz, W.H., Bandini, L.G., Morelli, J.A., Peers, K.F., \& Ching, P.L. (1994). Effect of sedentary activities on resting metabolic rate. Am J Clin Nutr. 59(3):556-559.

Fogelholm, M., Nuutinen, O., Pasanen, M., Myohanen, E., \& Saatela, T. (1999). Parent-child relationship of physical activity patterns and obesity. Int J Obesity. 23(12):1262-1268.

Garn, S. M., Clark, D. C., Lowe, C. U., Forbes, G., Owen, G. M., Smith, N. J., Weil Jr., W. B., Nichaman, M. Z., Johnsen, E., \& Rowe, N. (1975). Nutrition, growth, development, and maturation: findings from the ten-state nutrition survey of 1968-1970. Pediatrics 56(2):306-319.

Golan, M., Weizman, A., Apter, A., \& Fainaru, M. (1998). Parents as the exclusive agents of change in the treatment of childhood obesity. Am J Clin Nutr. 67(6):1130-1135.

Gozal, D. (1998). Sleep-disordered breathing and school performance in children. Pediatrics 102(3): 616-623.

Jackson, M. Y. (1993). Height, weight, and body mass index of American Indian schoolchildren, 1990-1991. J Am Diet Assoc. 93(10):1136-1140.

Janssen, I., Craig, W.M., Boyce, W.F., \& Pickett, W. (2004). Associations between overweight and obesity with bullying behaviors in school-aged children. Pediatrics 113(5):1187-1194.

Morrison, J.A., Barton, B.A., Biro, F.M., Daniels, S.R., \& Sprecher, D.L. (1999). Overweight, fat patterning, and cardiovascular disease risk factors in black and white boys. $J$ Pediatr. 135(4):451-457.

Nguyen, V.T., Larson, D.E., Johnston, R.K., \& Goran, M.I. (1996). Fat intake and adiposity in children of lean and obese parents. Am J Clin Nutr. 63(4):507-513.

Richardson, S., Hastorf, A., Goodman, N., \& Dornbusch, S. (1961). Cultural uniformity in reaction to physical disabilities. Am Sociol Rev. 26(2):241-247.

Rozin, P. (1990). Development in the food domain. Dev Psychol. 26(4):555-562.

Sjoberg, R.L., Nilsson, K.W., \& Leppert, J. (2005).

Obesity, shame, and depression in school-aged children: a population-based study. Pediatrics 116(3):e389-395.

Strauss, R.S., \& Pollack, H.A. (2003). Social marginalization of overweight children. Arch Pediatr Adolesc Med. 157(8):746-752.

U.S. Department of Health and Human Services. (2012). Childhood obesity. Retrieved from http://aspe.hhs.gov/ health/reports/child_obesity/\#_ftnref4 